\title{
Learning Strategies for Mobile-Assisted Seamless Learning: A Students' Initial Perceptions
}

\author{
Hasan Baharun*, Chusnul Muali, Muhammad Mushfi El Iq Bali, Fathor Rozi, Luluk \\ Nafisatur Rodiah, Zainabal Munawaroh and Siti Aminah
}

\author{
Islamic Faculty, Nurul Jadid University, Paiton, Probolinggo, East Java, Indonesia \\ *Corresponding author.Email: ha54nbaharun@gmail.com
}

\begin{abstract}
This study aims to analyze the management of learning during a pandemic using a mobile-assisted seamless learning approach at SMP Lubbul Labib, Maron, Probolinggo, East Java, Indonesia. This study uses a qualitative approach with case study. Data collection techniques are carried out through observation, interviews, and documentation. The data analysis is carried out circularly, starting from display data, data reduction, and concluding The results showed that the learning strategy through cellular aids in increasing student learning motivation was carried out through; making learning planning, determining learning objectives and targets, using methods, utilizing learning media, and assessing which are carried out in a planned and systematic manner
\end{abstract}

.Keywords: Learning Strategies, Mobile-Assisted Seamless Learning, Students

\section{INTRODUCTION}

Education is a very important tool for human survival [1]. This is because education is a sector that can create human intelligence in carrying out their lives. Whereas learning and learning are two things that are closely related and cannot be separated in educational activities. Learning and learning is said to be a form of education which creates an interaction between teachers and students [2]. Learning is also a series of activity plans which include the use of methods and the use of various resources or strengths in learning and are arranged to achieve a specific goal [3]. In learning activities, a teacher must be able to plan carefully about steps or learning and learning activities as a form of realizing competence as a professional. In addition to mastering the material and methods, teachers must also be able to do various things in increasing learning motivation for students or learners, especially during this pandemic.

With this pandemic, the government has made policies regarding learning activities that must be carried out online for all levels of education. SMP Lubbul Labib, Probolinggo, East Java, Indonesia, is one of the schools implementing this policy. The learning media used is Mobile-Assisted Seamless Learning media. Through these media, it is expected to provide an effective and efficient learning atmosphere. Learning that can create active, creative, and innovative students. Learning that provides deep meaning for students in their lives.

Mobile-Assisted Seamless Learning is a learning model that contains the concept of continuity in the learning process that occurs without time and space limits [4], by utilizing technology and information media. This learning can be done anytime, anywhere without a time limit [5]. Mobile-Assisted Seamless Learning is a new generation of learning using electronic devices as a means of delivering learning material. This media is very suitable for use during the Covid 19 pandemic, where learning must be carried out using psychological distancing and carried out online at home.

Many researchers have reviewed the importance of MobileAssisted Seamless Learning, including; Muhammad Berlin Al Ausi \& M. Luthfi Abdillah said that seamless learning has a significant influence on students' vocabulary mastery [6]. This was reinforced by Ulfa who stated that the success of Mobile Seamless Learning was due to the learning model containing the concept of continuity in the learning process that occurred without time and space limits [7]. Meanwhile, Umi Salamah, et. al said that to increase the 
effectiveness of seamleass learning in vocational higher education, a different learning model is needed [8].

Departing from the foregoing, there is a space that has not received the attention of other researchers and is the uniqueness of this study, namely the application of MobileAssisted Seamless Learning which was carried out during the Covid-19 pandemic which uses distance learning to arouse student learning motivation.

Mobile-Assisted Seamless Learning has a significant role in learning activities at SMP Lubbul Labib Maron, Probolinggo, where teachers try to provide online learning as part of the risk mitigation of Covid-19.

This study aims to analyze the efforts to analyze the management of learning using the approach of cellular tools during the Covid 19 period.

\section{METHODOLOGY}

This research uses a qualitative approach with a case study, with the research site at SMP Lubbul Labib, Maron, Probolinggo, East Java, Indonesia. Sources of data consisted of several people who have information about the theme raised and were selected by purposive sampling technique. Data collection techniques are carried out through observation of ongoing learning activities, interviews with several teachers and students, and documentation. while the data analysis was carried out circularly, starting with data display, data reduction, and drawing conclusions.

\section{RESULTS AND DISCUSSION}

The results showed that the learning strategy through cellular aids in increasing student motivation can be presented as follows Figure 1.



Figure 1 Learning strategy

First, making lesson plans. Learning planning activities at SMP Lubbul Labib Maron, Probolinggo were carried out thorough learner analysis. In this case, the teacher first analyzes the learning characteristics and conditions of students, both psychologically, sociologically, and in other aspects, such as; readiness in learning, student background, intelligence, motivation to learn, and so on.

This learner analysis is intended to obtain early information about the characteristics of students as a whole so that it will provide an overview of the teacher about what must be prepared. Through learner analysis, teachers will be able to predict the approaches and strategies that will be carried out in learning activities, so that student learning motivation increases and learning targets will be achieved optimally during the Covid pandemic.

Table 1 Learner Analysis

\begin{tabular}{cl}
\hline Activities & \multicolumn{1}{c}{ Information } \\
\hline Learner & Student learning characteristics \\
analysis & Student learning styles \\
& Readiness to learn \\
& $\begin{array}{l}\text { Student background } \\
\text { motivation to learn }\end{array}$ \\
\hline
\end{tabular}

Second, determining learning goals and targets. In this case, the teacher makes learning objectives based on learner analysis and students' initial competences, by utilizing electronic tools in the form of smartphones through the Whats App application. The determination of learning objectives is the target achievement that the teacher wants to achieve in online learning activities through the use of electronic media.

Third, the use of teaching methods and strategies. In this case, the teacher uses a student-centered approach, in which students are required to be active in their learning activities. In this case, the teacher provides learning tutorials according to predetermined learning targets, so that they are easily understood by students.

The strategies used by teachers in distance learning at SMP Lubbul Labib Maron, Probolinggo through the use of learning cars are as follows; 1) the teacher provides the material to the students. 2) Then the teacher gives instructions to work on the questions about the material. 3) After the material is done, students report their assignments via WhatsApp. In reporting assignments, they must be accompanied by a name so that the teacher can easily provide an assessment to students who participate in the WhatsApp.

While the learning media used is the Whats App as a medium for discussion. WhatsApp media can also be used as a group communication media called WhatsApp Group. In this case, each class has a Whats App group to provide information to students related to the material to be delivered by the teacher.

Fourth, an assessment of the learning outcomes of students after they carry out learning activities online. The assessment used for students during this pandemic is in the form of a portfolio assessment, where the teacher assesses the student's performance on each material presented, using the authentic assessment principle. Through an authentic assessment based on performance assessment, student motivation can be increased.

Advances in technology have an impact on advances in education. Information technology can be used to communicate and exchange information [3]. Mobile learning is understood as a learning and teaching method that uses electronic media (connected to an Internet connection) to deliver mobile-based materials and guidance[9]. Mobile learning makes it easy for users to get a lot of material from the Internet and on a mobile basis. Mobile learning refers to the use of handheld devices such as cell phones, laptops and information technology devices that will be widely used in teaching and learning, in this 
case we focus on mobile devices (cell phones) with several applications in them, such as Whats App, Telegram, IMO., Instagram, and so on. The purpose of developing mobile learning itself is a long-life learning process, students can be more active in the learning process [10], save time because if it is applied to the learning process, students do not need to be present in class just to collect assignments, just send the assignment. Through applications on cell phones which will indirectly improve the quality of the learning process itself [11].

In this case, the teacher acts as a facilitator for students. In other words, it is students who must become the subject of learning completely[12]. This illustrates that students must find sources of information, process the information so that it becomes knowledge, and students are finally able to build their knowledge [13]. Apart from all these things, the teacher still has a role in guiding students[14]. The product that you want to produce from this learning is a learning media with distance learning characteristics by utilizing mobile-assisted seamless learning.

The media developed has various interactive learning features such as the availability of interactive learning materials, animation and illustrations, simulations, and a collection of conceptual understanding practice questions.[15] Through this, it is hoped that student motivation can increase.

Motivation is understood as a series of efforts to provide certain conditions so that someone wants and wants to do something, and if they don't like it, they will try to avoid[16]. So motivation can be stimulated by external factors, but motivation grows within a person [17], then learning will be successful when students have motivation to learn [18].

Therefore, teachers need to foster student motivation [19]. To obtain optimal learning outcomes, teachers are required to be creative in arousing student motivation[20]. Educational motivation is very important because it can determine the success of students in learning[21].

Motivation to learn can be classified into two parts, namely intrinsic motivation [22] (a state that comes from within the student himself which can encourage him to take learning actions), and extrinsic motivation (conditions that come from outside the individual student that encourage him to carry out learning activities) [23].

In learning activities, motivationcan be said to be the overall driving force within students that raises, ensures continuity, and provides direction for learning activities, so that it is hoped that existing goals can be achieved. Learning without motivation is likely to be far from successful [24]. In this case, motivation is the driving force that gives rise to learning activities, so that the expected learning objectives can be achieved.

\section{CONCLUSION}

The learning strategy through cellular aids in increasing student learning motivation was carried out through; making learning planning, determining learning objectives and targets, using methods, utilizing learning media, and assessing which are carried out in a planned and systematic manner. Mobile-Assisted Seamless Learning is a learning model that contains the concept of continuity in the distance learning process which can increase student learning motivation. Mobile-Assisted Seamless Learning is a new generation of learning using electronic devices as a means of delivering learning material.

\section{REFERENCES}

[1] M. Zamroni, Ilyasin, M. Tohet, Multicultural education in a religious life: Developing harmony among religions in southeast asia," Proc. Int. Conf. Ind. Eng. Oper. Manag. 3791-3801, 2020.

[2] A. Pane, M. Darwis Dasopang, Belajar Dan Pembelajaran, FITRAH Jurnal Kaji Ilmu-ilmu Keislaman, 3 (2) (2017) 333-352, DOI: https://doi. org/10.24952/fitrah.v3i2.945.

[3] H. Baharun, Management information systems in education: the significance of e-public relation for enhancing competitiveness of higher education, Journal of Physics Conference Series, 1175 (1) (2019) 012151. DOI: https://doi.org/ 10.1088/17426596/1175/1/012151

[4] L. H. Wong, C. K. Looi. What seams do we remove in mobile-assisted seamless learning? A critical review of the literature. Computers \& Education, 57 (4) (2011) 2364-2381. DOI: https://doi.org/10.1016/j.compedu.20 11.06.007

[5] Y. Kali, K. S. Levy, R. Levin-Peled, T. Tal. Supporting outdoor inquiry learning (SOIL): Teachers as designers of mobile-assisted seamless learning. British journal of educational technology, 49 (6) (2018) 1145-1161. DOI: https://doi.org/10.1111/ bjet12698

[6] M. Berlin, A. Ausi, M. L. Abdillah, Penggunaan Strategi Seamless Learning pada Penguasaan Kosa Kata Siswa, Jurnal Pendidikan, 29 (3) (2020) 197-202.

[7] S. Ulfa, Mobile Seamless Learning' Sebagai Model Pembelajaran Masa Depan, Jurnal Inovasi dan Teknolohi Pembelajaran, 1 (1) (2017) 11-19. DOI: https://doi.org/10.17977/um031v1i12014p011.

[8] U. Salamah, I. N. S. Degeng, P. Setyosari, S. Ulfa, Development of Instructional Design Comprehensive Performance Improvement Based on Seamless Learning (CPISL) Model in Vocational College, International Journal Research Review, 6 (7) (2019) 105-113.

[9] P. Novantara, Implementasi Dan Efektifitas Mobile Learning Dengan Menggunakan Metode Synchronous Dan Asynchronous Learning Pada Pembelajaran Bahasa Inggris Di Universitas Kuningan Berbasis 
Android, Buffer Informatika, 3 (1) (2017) 22-27. DOI: https://doi.org/10.25134/buffer.v3i1.932.

[10] A. Chimpololo, An analysis of heutagogical practices through mobile device usage in a teacher training programme in Malawi, Journal Learning Devices, 7 (2) (2019) 190-203.

[11] Y. F. Lan, Y. S. Sie. Using RSS to support mobile learning based on media richness theory. Computers \& education, 55 (2) (2010) 723-732. DOI: https://doi. org/10.1016/j.compedu.2010.03.005

[12] K. Selvi, Teachers' competencies. Cult. Int. J. Philos. Cult. Axiolog., 7 (1) (2010) 167-175. DOI: https://doi. org/10.5840/cultura20107133.

[13] C. Muali, S. Minarti, M. Taufik Qurohman, Haimah. Analysis of metacognitive capability and student learning achievement through edmodo social network, Journal of Physics Conference Series, 1175 (1) (2019) 012150. DOI: https://doi.org/10.1088/1742$6596 / 1175 / 1 / 012150$

[14] A. Erkan, Impact of Using Technology on Teacher-Student Communication/Interaction: Improve Students Learning, World Journal Education, 9 (4) (2019) 30-40. DOI: https://doi.org/10.5430/wje.v9n 4 p30.

[15] C. Muali, Free Online Learning Based on Rich Internet Applications; The Experimentation of Critical Thinking about Student Learning Style, Journal of Physics Conference Series, 1114 (1) (2018) 012024. DOI: https://doi.org/10.1088/1742-6596/1114/1/012024

[16] A. Syakroni, C. Muali, H. Baharun, Motivation And Learning Outcomes Through The Internet Of Things: Learning In Pesantren, Journal of Physics Conference Series, 1363 (1) (2019) 012084. DOI: https://doi.org/10.1088/1742-6596/1363/1/012084.

[17] E. Ismanto, M. Novalia, P. B. Herlandy, Pemanfaatan Smartphone Android Sebagai Media Pembelajaran Bagi Guru Sma Negeri 2 Kota Pekanbaru, Jurnal Pengabdian UntukMu NegeRI, 1 (1) (2017) 42-47. DOI: https://doi.org/10.37859/jpumri. v1i1.33.

[18] L. L. Moore, D. K. Grabsch, C. Rotter, Using Achievement Motivation Theory to Explain Student Participation in a Residential Leadership Learning Community, Journal Leadership Education, 9 (2) (2010) 22-34. DOI: https://doi.org/10.12806/V9/I2/RF

[19] S. Islam, C. Muali, I. M. Ghufron, Moh Idil, 'To Boost Students' Motivation and Achievement through Blended Learning To Boost Students Motivation and Achievement through Blended Learning, Journal Physics Conference Series, 1114 (1) (2018) 1-11.
[20] G. Engin, An Examination of Primary School Students Academic Achievements and Motivation In Terms of Parents Attitudes, Teacher Motivation, Teacher Self-efficacy and Leadership Approach, International Journal Progression Education, 16 (1) (2020) 257-276. DOI: https://doi.org/10.29329/ijpe.20 20.228 .18

[21] D. L. Apriliyanti, The Correlation Between Efl Learners' Motivation on English Course and Their English Learning Achievement, TARBIYA Journal Education Muslim Society, 4 (2) (2017) 232-239. DOI: https://doi.org/10.15408/tjems.v4i2.6401

[22] C. Mega, L. Ronconi, and R. De Beni, What makes a good student? How emotions, self-regulated learning, and motivation contribute to academic Achievement, Journal Education Psychology, 106 (1) (2014) 121131. DOI: https://doi.org/10.1037/a0033546

[23] K. Hajhashemi, N. Caltabiano, N. Anderson, Multiple Intelligences, Motivations and Learning Experience Regarding Video-Assisted Subjects in a Rural University, International Journal Instrumentation 11 (1) (2018) 167-182. DOI: https://doi.org/10.12973/ iji.2018.11112a

[24] S. Haryono, Pengaruh Kedisiplinan Siswa Dan Motivasi Belajar Terhadap Prestasi Belajar Siswa Pada Mata Pelajaran Ekonomi, Jurnal Ilmu Kependidikan, 3 (3) (2016) 261-274. 